Gonçalves, A., A. L. Santos \& I. Duarte 2014. (Pseudo-)Inflected infinitives and Control as Agree. In Karen Lahousse \& Stefania Marzo (eds.) Selected papers from 'Going Romance' Leuven 2012. Amsterdam: John Benjamins. pp. 161-180.

\title{
(Pseudo-)Inflected infinitives and Control as Agree
}

\author{
Anabela Gonçalves, Ana Lúcia Santos, Inês Duarte
}

\begin{abstract}
This paper discusses the distribution of inflected infinitives in standard and non-standard European Portuguese. In the standard variety, inflected infinitives are generally available in non-obligatory control contexts (subject and adjunct clauses), but can only occur in obligatory control contexts when the temporal orientation of the complement is not specified by the matrix verb. An explanation for this fact is offered along the lines of an Agree theory of control. This analysis also accounts for the possibility of controlled inflected infinitives, which occur in non-standard varieties of European Portuguese. Controlled inflected infinitives bear morphological inflection but do not license nominative. We argue that these non-standard inflected infinitives make the Agree operation underlying control visible (this operation does not have a morphologically overt counterpart in the standard grammar of EP). We also argue that some speakers accept these pseudoinflected infinitives as a strategy to make partial control readings explicit in independent tense contexts.
\end{abstract}




\title{
(Pseudo-)Inflected infinitives and Control as Agree ${ }^{1}$
}

\begin{abstract}
This paper discusses the distribution of inflected infinitives in standard and non-standard European Portuguese. In the standard variety, inflected infinitives are generally available in non-obligatory control contexts, but can only occur in obligatory control contexts when the temporal orientation of the complement is not specified by the matrix verb. An explanation for this fact is offered along the lines of an Agree theory of control. This analysis also accounts for the possibility of controlled inflected infinitives, which bear morphological inflection but which cannot license nominative, occurring in non-standard varieties of European Portuguese: they are considered the result of the spell out of the Agree operation that takes place in control contexts.
\end{abstract}

\section{Introduction}

Several studies on the distribution of inflected infinitives in E(uropean) P(ortuguese) (Raposo 1987, Ambar 2007, a.o.) establish a strong correlation between these infinitives and embedded CPs with independent tense on the basis of lexical properties of matrix verbs.

Under the standard GB account of inflected infinitives presented in Raposo (1987), the availability of inflected infinitives is a consequence of the interaction of two parameters, the Null Subject Parameter and the Infl Parameter: the inflected infinitive results from the possibility of having an infinitive Infl node with overt agreement features (the Infl Parameter), combined with the option of a Agr specified for Case (the Null Subject Parameter). Raposo (1987) also claims that inflected infinitives only occur as complements to verbs selecting for tensed CPs (i.e. what has been renamed 'complements with independent tense'). If so, and if tense (in)dependence is a purely lexical property, we should not expect to find any correlation between tense (in)dependence and specific syntactic configurations, that is, a particular verb should select for either a tense independent or a tense dependent complement, regardless of the finiteness of the CP complement, contrary to fact (see (1)). Moreover, since PRO is not allowed to co-occur with overt phi-features in infinitival clauses, controlled inflected infinitives are not expected, a prediction borne out for standard EP but not for non-standard varieties of this language (see (2)).
(1) a.
$O$ João quis
que a Maria saísse
amanhã.
the João wanted that the Maria leave.SBJV tomorrow
'João wanted Maria to leave tomorrow.'
b. *O João quis sair amanhã.
the Joao wanted leave.INF tomorrow
(2) Decidiram irem todos os presentes à Lagoa 
decided.3PL go.INF.3PL all the presents to.the Lagoa 'All those who were present decided to go to Lagoa.'

(https://sites.google.com/site/boletinsarquivo/)

Thus, this study aims at (a) showing that tense (in)dependence of a $\mathrm{CP}$ complement is not only dependent on lexical properties of the main predicate but also on the syntactic configuration; (b) arguing that the lexical property of temporal orientation (and not tense independence) explains the distribution of inflected infinitives; (c) adding a new argument for an account of the inflected infinitive that takes the occurrence of overt inflection in the infinitive and the licensing of pro/overt subject as two independent facts, based on a theory of control as Agree and on the occurrence of controlled inflected infinitives (or pseudo-inflected infinitives) in complement clauses of non-standard EP, such as (2).

The paper is structured as follows: in section 2, we briefly describe the distribution of inflected infinitives in standard EP both in obligatory control (OC) and non-obligatory control (NOC) contexts; section 3 presents the analysis of standard inflected infinitives in subject OC contexts and its consequences for the distribution of tense (in)dependence, as well as the role of temporal orientation in those contexts; in section 4, we suggest an approach to pseudo-inflected (or controlled inflected) infinitives in nonstandard varieties of EP as a corollary of the analysis sketched in section 3; finally, we make some concluding remarks in section 5. Throughout the paper, only subject control will be considered.

\section{The distribution of inflected infinitive in obligatory control vs. non obligatory control contexts}

As it is well known, a long and lively debate on what counts as the best theory of control has been going on in the literature. Since this debate is not the focus of this paper, we will simply state that we adopt Landau's (2000, 2004) approach to control as Agree, and we believe that the facts presented here may ultimately be seen as an argument in favor of this theory.

Landau argues for the distinction between raising and control and refines the distinction between $\mathrm{OC}$ and NOC contexts, showing that locality conditions determine the distribution of OC: it applies only in $\theta$-marked infinitives internal to VP, that is, in complement clauses, whereas NOC applies in island contexts, that is, in preverbal subject infinitives and in adjunct clauses. This distribution is accounted for if OC, but not NOC, "involves an Agree relation between the matrix functional head F [T, in the case of subject OC] that agrees with the controller and PRO/T-AGR." (Landau 2000, 14).

The divide between OC and NOC is particularly interesting in standard $\mathrm{EP}$, a language with inflected infinitive, which is generally available in 
NOC contexts (see (3)-(4)), but severely restricted in OC contexts (see (5)(7)).

(3) É melhor [nós/pro irmos ao cinema]. is better we go.INF.1PL to.the cinema

'It is better that we go to the cinema.'

(4) Os miúdos telefonaram [para os pais os irem the kids called for the parents CL.3PL go.INF.3PL buscar]. pick up

'The kids called in order for the parents to pick them up.'

(5) a. O júri declarou irem dois candidatos à the jury declared go-INF.3PL two candidates to.the final.

final

'The jury declared that two candidates go to the final.'

b. $\quad * O$ júri declarou dois candidatos irem the jury declared two candidates go.INF.3PL à final.

to.the final

(6) a. $O$ júri lamentou $\left[{ }_{C P}\right.$ irem poucos candidatos the jury regretted go-INF.3PL few candidates à final]. to.the final 'The jury regretted the fact that few candidates (would) go to the final.'

b. $O$ júri lamentou [IP poucos candidatos irem the jury regretted few candidates go.INF.3PL à final].

to.the final

(7) a. Ospais quiseram ir ao cinema. the parents wanted go.INF to.the cinema 'The parents wanted to go to the cinema.'

b. *Os pais quiseram irem os meninos the parents wanted go.INF.3PL the children ao cinema. to.the cinema

c. *Os pais quiseram os meninos irem the parents wanted the children go.INF.3PLU ao cinema. to.the cinema.

d. *Os pais quiseram irem ao cinema. the parents wanted go.INF.3PL to.the cinema

e. *O pai quis irem ao cinema. the dad wanted go.INF.3PL to.the cinema 
The examples in (3) and (4) illustrate the free distribution of inflected infinitives in NOC contexts: subject and adjunct clauses, respectively. On the contrary, in OC contexts, there is a sharp contrast depending on matrix verbs: as Raposo (1987) showed, complements to declarative, factive and epistemic verbs allow the occurrence of inflected infinitive (see (5), (6)), subject-verb inversion being obligatory with declarative verbs (see (5b) vs. (6b)); in contrast, complements to volitional verbs exclude it (see (7)). These general facts characterize the standard distribution of inflected infinitives. As it is well known, Raposo treated the contrast between (5)-(6) and (7) as a consequence of a purely lexical property of the matrix verbs: the fact that they did or did not select for an independent tensed complement clause. However, as we show in the next two sections, his definition of tense (in)dependence is not accurate enough and hence we will both provide a refinement of this concept and examine the role of another temporal relation between the embedded and the matrix clauses in the licensing of inflected infinitives: temporal orientation.

\section{The role of tense (in)dependence and temporal orientation in the distribution of inflected infinitive in $\mathrm{OC}$ contexts $^{2}$}

\subsection{Tense (in)dependence as a result of a particular syntactic configuration}

As mentioned in the introduction of this paper, Raposo's (1987) classical analysis of EP inflected infinitives associates the distribution of inflected infinitives with a lexical property of matrix verbs: the possibility of selecting for a tensed $\mathrm{CP}$, that is, a type of complement that could be renamed as an independent tense complement. However, examples (8) and (9) show that independent tense in an infinitival complement is not a sufficient condition for the occurrence of inflected infinitives in standard EP, contrary to Raposo's prediction. Assuming that the co-occurrence of the embedded future-oriented adverbial amanhã 'tomorrow' with a matrix verb in the past tense is a reliable test of tense independence, we conclude that both decidir 'to decide' and prometer 'to promise' select for independent tense complements. Yet, inflected infinitive is not allowed in these contexts, as the (b) examples show.

(8) a. Eles $s_{i}$ decidiram $[-]_{i}$ ir ao cinema amanhã. they ${ }_{i}$ decided $\quad[-]_{i}$ go-.INF to.the cinema tomorrow 'They decide to go to the cinema tomorrow.'

b. *O João $o_{i}$ decidiu $[-]_{j}$ irmos ao cinema the João ${ }_{i}$ decided $[-]_{\mathrm{i}}$ go.INF.1PL to.the cinema (amanhã). (tomorrow)

(9) a. Eles prometeram acabar o trabalho amanhã. they promised finish.INF the work tomorrow 

'They promised to finish the work tomorrow.'
b. *Eles prometeram acabarmos o trabalho amanhã. they promised finish.INF.1PL the work tomorrow

The problem is not solved by more recent definitions of (in)dependent tense. Ambar (2007) also resorts to this concept in order to account for the distribution of indicative, subjunctive and inflected infinitive in EP complement clauses. As Raposo (1987), she argues that (in)dependent tense is a lexical property of matrix verbs, which may select for either [+T] (independent embedded tense) or [-T] (dependent embedded tense). Moreover, Ambar (2007) claims that tense (in)dependence is correlated to the possibility of having the $t($ ense)-features on $\mathrm{C}-\mathrm{V}$ valued internally to the embedded CP (a tense independent context) or outside it, in the matrix domain (a tense dependent context): inflected infinitives are licensed inside complete CPs, i.e., CPs whose features are internally valued. Thus, tense (in)dependence is already accounted for both in lexical and in syntactic terms, although leaving the contrast in (1) unaccounted for.

Within the theory of control as Agree, Landau (2000, 2004) suggests a three-way distinction of embedded tense: anaphoric selected tense; dependent selected tense and free (non-selected) tense. Dependent tense is defined as describing "a situation where the tense of the embedded clause is constrained by (though, crucially, not necessarily identical to) the matrix tense." (Landau, 2004, 822). Landau $(2004,851)$ specifically suggests that EP inflected infinitives are incompatible with irrealis tense (although they are compatible with realis dependent tense, as in factives, or independent tense, as in declarative and epistemic complements or in subject and adjunct clauses). Nevertheless, the following sentence shows that inflected infinitive is compatible with irrealis ${ }^{3}$ :

(10) Ela acredita acabarem os primos o trabalho she believes finish.INF.3PL the cousins the work amanhã.

tomorrow

'She believes that her cousins will finish the work tomorrow.'

Furthermore, Landau tests selected tense (anaphoric vs. dependent) with deictic temporal adverbials (such as yesterday / tomorrow) whose features are incompatible with the tense features of the matrix verb. He concludes that: (a) in dependent selected tense (or tensed) contexts, a future-oriented adverbial is allowed despite the morphological tense of the matrix verb; (ii) in anaphoric (or untensed) contexts, this kind of conflicting temporal information produces ungrammatical results (Landau 2004, 831-833). Yet, this type of test is not accurate, since the deictic / non-deictic interpretation of adverbials may change the grammaticality judgments (see (11a) and (11b)).

(11) a. *O João quis comprar o jogo amanhã. 

the João wanted buy.INF the game tomorrow
b. $O$ João quis compraro jogo no dia seguinte. the João wanted buy.INF the game in.the day after 'João wanted to buy the game the next day.'

Although both temporal expressions occurring in the infinitival domain have a future interpretation, in (11a) the adverb amanhã 'tomorrow' forces the temporal perspective point (TPpt) of the embedded sentence to be the utterance time whereas in (11b) the temporal PP no dia seguinte 'the next day' forces the TPpt of the embedded sentence to be the time of the matrix clause. This difference is crucial to the grammaticality of the sentences.

Gonçalves, Cunha \& Silvano (2010) provide a finer-grained definition of tense dependence, which instead involves the semantic concepts of temporal domain (Declerck, 1991) and TPpt (Kamp \& Reyle, 1993). The temporal domain concerns the time interval taken up by a situation or by a number of situations that are temporally related to each other; TPpt is defined as the point from which a situation is viewed. Thus, according to Gonçalves, Cunha \& Silvano (2010), tense dependence obtains when two situations share the same temporal domain; in this case, the TPpt of the embedded infinitive is the time of the matrix clause (Silvano 2002), which precludes deictic adverbials related to the Utterance Time. This is the case of (11b). If the situations do not share the same temporal domain and the TPpt of the embedded clause may be different from the time of the matrix clause, an independent tense context results (see (12)).

(12) a. O João decidiu comprar o jogo amanhã. the João decided buy.INF the game tomorrow 'João decided to buy the game tomorrow.'

b. $O$ João decidiu comprar o jogo no dia seguinte. the João decided buy.INF the game in.the day after 'João decided to buy the game the next day.'

Some generalizations become clear when we use this definition. First, there is a strong association between tense independence and NOC contexts: a structurally opaque domain for OC (that is, a NOC context) is always tense independent, as in sentential subjects (13) and adjuncts (14).

(13) Ir ao cinema amanhã não agradou à Maria. go.INF to.the cinema tomorrow not pleased to.the Maria 'To go to the cinema tomorrow did not please Maria.'

(14) A Maria comprou cervejas para beber amanhã. the Maria bought beer to drink tomorrow 'Maria bought some beer to drink tomorrow.'

Second, inflected infinitival clauses always show independent tense, as illustrated in (15), with a sentential subject including a deictic adverb 
incompatible with the future meaning of the auxiliary ir 'to go' in the main clause, and also (16), with a complement clause:

(15) Termos ido ao cinema ontem não lhe have.INF.1PL gone to.the cinema yesterday not him vai agradar.

go.IND.3SG please.INF

'The fact that we went to the cinema yesterday will not please him.'

(16) Os pais lamentaram irmos ao cinema amanhã. the parents regretted go.INF.1PL to.the cinema tomorrow 'The parents regretted the fact that we will go to the cinema tomorrow.'

Finally, according to Gonçalves, Cunha \& Silvano's (2010) definition, tense (in)dependence is not a purely lexical property of matrix verbs but rather a temporal relation which obtains in specific syntactic structures with specific verbs. The fact that an obligatory tense dependence reading is only generated in the infinitival complement clauses of a particular subset of verbs is the lexical component of this property. In other words, it is the semantic effect of a particular syntactic configuration which may only obtain when some OC verbs occur. This accounts for the fact that some OC verbs obligatorily occur with tense dependent infinitive complements (see (17)), whereas others do not (see (18)).

(17) *Os pais quiseram ir ao cinema amanhã. the parents wanted go.INF to.the cinema tomorrow 'The parents wanted to go to the cinema tomorrow.'

(18) Os pais decidiramir ao cinema amanhã. the parents decided go.INF to.the cinema tomorrow 'The parents decided to go to the cinema tomorrow.'

Given that obligatory tense dependence only occurs in OC contexts (it never occurs in non-inflected infinitive domains in NOC contexts nor in inflected infinitive complement clauses), we hypothesize that tense dependence may be seen as a possible side effect of subject control. Subject control involves the formation of an Agree chain (Landau 2000) having matrix $\mathrm{T}$ as a probe, as illustrated in the simplified representation of subject control structures in (19). In section 3.3, we explore the idea that an Agree chain involving $[\mathrm{T}]$ features in matrix $\mathrm{T}$ and embedded $\mathrm{C}-\mathrm{T}$ may generate a tense dependent reading.

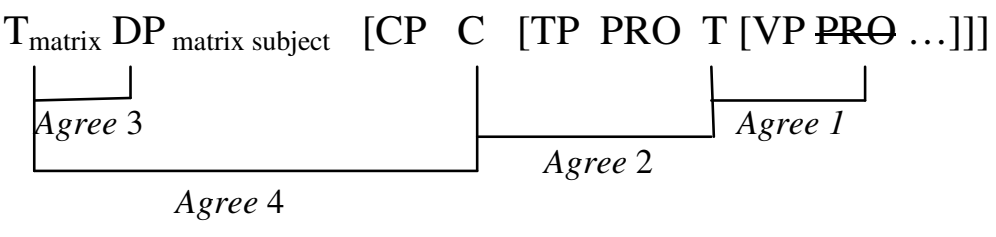


In sum, Raposo's (1987) correlation between independent tense and inflected infinitives should be taken in the opposite way: true inflected infinitives are not restricted to independent tense contexts; instead, true inflected infinitive clauses do not show up with dependent tense because the relevant Agree chain cannot be formed, as it happens in control structures.

\subsection{Temporal orientation and the licensing of inflected infinitives}

In the previous section, we accounted for the relation between tense independence and inflected infinitives: an inflected infinitive clause is always an independent tense context. However, several questions remain, namely: which property underlies the distribution of inflected infinitives in OC contexts? What distinguishes (20b) from (21b)?

(20) a. $O$ João $_{i}$ afirmou []$_{i}$ ir ao cinema amanhã. the João said $\quad[-]_{i}$ go to.the cinema tomorrow 'João said that he will go to the cinema tomorrow.'

b. O João $o_{i}$ afirmou $[-]_{j}$ irmos ao cinema the João said go.INF.1PL to.the cinema amanhã. tomorrow 'João said that we will go to the cinema tomorrow.'

(21) a. O João $o_{i}$ decidiu $[-]_{i}$ ir ao cinema amanhã. the $\mathrm{João}_{\mathrm{i}}$ decided $[-]_{\mathrm{i}}$ go to.the cinema tomorrow 'João decided to go to the cinema tomorrow.'

b. *O João decidiu $[-]_{j}$ irmos ao cinema the João $o_{i}$ decided [-] $]_{i}$ go.INF.1PL to.the cinema amanhã.

tomorrow

We suggest that the relevant difference is the temporal orientation of the embedded sentence. The matrix verb in (20b) does not specify the temporal orientation of the embedded sentence, that is, it is neuter (in the sense of Cunha \& Silvano 2006) with respect to the temporal location of its complement clause (see (22)); on the contrary, the matrix verb in (21b) forces a future interpretation on its complement (see (21a) vs. (23)). In other words, the two predicates differ with respect to its temporal orientation, a lexical property of matrix verbs which determines the temporal location of the situation described in the embedded sentence: anteriority, posteriority or overlapping (Duarte, Gonçalves \& Santos 2012).

(22) a. O João afirmou votar nesses candidatos amanhã. the João said vote.INF in.those candidates tomorrow 'João said he will vote for thoe candidates tomorrow.'

(posteriority) 
b. O João afirmou ter votado nesses the João said have.INF voted in.those candidatos. candidates

'João said he had voted for those candidates.'

c. O João afirmou confiar nesses candidatos.

(anteriority) the João said trust.INF in.those candidates 'João said he trust those candidates.' $*$ João $o_{i}$ decidiu ter ido ao cinema
the João decided have.INF gone to.the cinema

(overlapping) . (anteriority)

Temporal orientation strongly correlates with the distribution of inflected infinitive. In fact, inflected infinitive is available in complement clauses whenever the matrix verb does not specify the temporal orientation of the embedded sentence (see the case of afirmar 'to say' in (22)). On the contrary, if the matrix verb specifies the temporal orientation of the infinitival complement, only non-inflected infinitive occurs and the embedded subject is obligatorily controlled, regardless of temporal (in)dependence (see the cases of decidir 'to decide' in (24), querer 'to want' in (25), and conseguir 'to manage' in (26)).

(24) Temporal orientation: posteriority - Tense independence

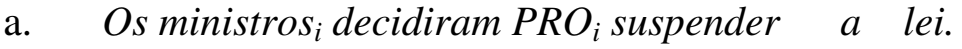
the ministers decided PRO suspend.INF the law

b. *Os ministros decidiram suspendermos a lei. the ministers decided suspend.INF.1PL the law

(25) Temporal orientation: posteriority - Tense dependence

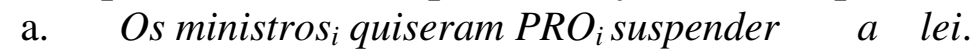
the ministers wanted PRO suspend.INF the law

b. *Os ministros quiseram suspendermos a lei. the ministers wanted suspend.INF.1PL the law

(26) Temporal orientation: overlapping - Tense dependence

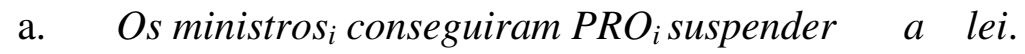
the ministers managed PRO suspend.INF the law

b. *Os ministros conseguiram suspendermos a lei. the ministers managed suspend.INF.1PL the law

In section 3.1, we suggested that in NOC contexts, the Agree operation between matrix $\mathrm{T}$ and embedded $\mathrm{C}$ cannot apply, and therefore the infinitival clause is always tense independent and the distribution of the inflected infinitive is free; in this case, temporal orientation of the embedded situation is not at stake, since the infinitival domain is not selected for by the 
matrix verb. Now, we suggest that in OC contexts, where the syntactic configuration always allows the Agree operation between matrix $\mathrm{T}$ and embedded $\mathrm{C}$, inflected infinitive is restricted to complements of matrix verbs with an unspecified temporal orientation. In what follows, we further explore this line of analysis and define in more precise terms not only how we define temporal orientation as a consequence of a lexical property of matrix verbs but also how we derive temporal dependence from control (an issue left open in section 3.1).

\subsection{The distribution of inflected infinitives in $O C$ contexts: refining the analysis}

The data presented so far empirically support the idea that $\mathrm{T}$ must be taken as a bundle of features including not only the classical t(ense)features, but also $\tau$ (temporal orientation) and TPpt (temporal perspective point, linked to tense dependence) features; these features of embedded T may be valued ( $\tau$. val; TPpt: val) or remain unspecified ( $\tau$ : ?; TPpt: ?) until the end of the derivation of the embedded CP phase, before it is merged with the matrix verb.

How do $\tau$ and TPpt-features account for the distribution of infinitives? Before answering this question, let us briefly distinguish pro from PRO. As Chomsky (2008), we assume that pro is identified by phi-features in the embedded CP; we also assume that it is licensed by a complete $\mathrm{CP}$, whose $\mathrm{T}$ is [ ${ }_{\mathrm{T}} \tau . v a l$; TPpt: val] at the end of the derivation. An incomplete [T] precludes the presence of pro and only allows for PRO. We agree with Landau (2000) that PRO has phi-features, which are valued under agreement with the controller.

Given the assumptions just stated and the facts described up until now, we suggest that we can define the distribution of the different types of infinitives by characterizing the set of specified features present in the embedded $\mathrm{C}^{\mathrm{o}}$ at the end of the $\mathrm{CP}$ phase and before it merges with the matrix predicate. We thus suggest that infinitives are licensed if one of the following conditions is observed ${ }^{4}$ :

1. A matrix predicate imposing a specified temporal orientation on its complement selects for a non-finite $\mathrm{CP}$ which is an incomplete phase (whose $[\mathrm{T}]$ features are at least partially unspecified). ${ }^{5}$ In this context, T does not license pro /nominative, so the $\mathrm{CP}$ is always controlled. The selection properties of the matrix predicate determine the degree of incompleteness of the $\mathrm{CP}$ :

(a) unspecified for phi-features and bearing [ [ ${ }_{\mathrm{T}} \tau$. ?; TPpt: val] (corresponding to a tense independent controlled complement, whose temporal orientation is determined by the matrix predicate, e.g, in the context of decidir 'to decide'); 
(b) unspecified for phi-features and bearing [т $\tau:$ ? ; TPpt: ?] (corresponding to the extreme defectiveness of a tense dependent controlled complement, e.g, in the context of querer 'to want). ${ }^{6}$

In these two cases, unspecified [T] features in the embedded $\mathrm{C}$ (at the end of the derivation of the embedded $\mathrm{CP}$ ) are specified through (matrix)T(embedded)C agreement, which also specifies phi-features in PRO (i.e. the Control operation) (see the schema in (19), section 3.1). In the case of 1(b), this gives rise to a tense dependence reading (therefore, only available in control contexts and a consequence of this particular syntactic configuration). ${ }^{7}$

2. A matrix predicate selecting for a complement with an unspecified temporal orientation merges with a non-finite $\mathrm{CP}$ with specified [T] features. This CP may be

(a) incomplete wrt phi-features, but complete wrt to $\tau$ and TPpt features, i.e. $\left[{ }_{\mathrm{T}} \tau\right.$. val; TPpt: val] (corresponding to a controlled tense independent complement). In this case, given the absence of phi-features, pro would not be identified; instead, phi-feature agreement between matrix $\mathrm{T}$ and embedded $\mathrm{C}$ identifies PRO in the embedded domain (see the case of afirmar 'to say' with non-inflected infinitive);

(b) complete, that is, [ ${ }_{\mathrm{T}} \tau$. val; TPpt: val], with phi-features internally valued (corresponding to an inflected infinitive complement; being complete, this CP is a phase opaque to the Agree relation with matrix T).

Given the analysis sketched here, nothing in principle precludes that incomplete $[\mathrm{T}]$ features co-occur with specified phi-features (a different situation, in addition to the options just stated). This is also in line with Sitaridou's (2006) claim that T-defectiveness does not necessarily correlate with phi-defectiveness. In the next section, we show that non-standard European Portuguese is taking this option and producing what we will show to be controlled inflected infinitives (or pseudo-inflected infinitives).

\section{Controlled (pseudo-)inflected infinitives in non-standard EP: a corollary of the analysis}

\subsection{The data}

In non-standard EP, written corpora present apparent counter-examples to the analysis outlined in the previous section:

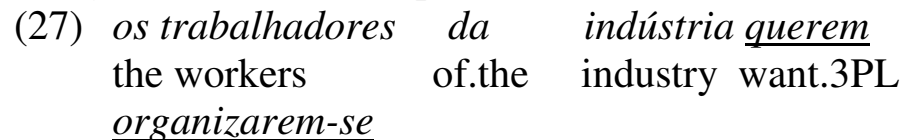


organize.INF.3PLU-CL

'industry workers want to organize themselves'

(CRPC, 2.0 2012, extraction using CPQWeb [12/2012])

(28) estão dispostas a tentar serem bem sucedidas are willing to try.INF be.INF.3PL well succeeded 'They are willing to try to be successful'

(29) Decidiram irem todos os presentes à Lagoa decided.3PL go.INF.3PL all the presents to.the Lagoa 'All those who were present decided to go to Lagoa.'

(https://sites.google.com/site/boletinsarquivo/)

(30) Alguns dirigentes socialistas não se mostram muito receptivos some leaders Socialist not CL show very receptive à proposta, preferindo concorrerem sozinhos to.the proposal preferring stand.INF.3PLU alone 'The proposal does not get much support from some socialist leaders, who prefer to run alone.'

(CETEMPúblico, par =ext69894-soc-93a-2)

Notice that the matrix verbs in (27)-(30) - querer 'to want', tentar 'to try', decidir 'to decide', and preferir 'to prefer' - select for a specified temporal orientation: their complements are future-oriented. Thus, are these cases counter-examples to the claim that inflected infinitives in subject OC are restricted to complements of verbs selecting for an unspecified temporal orientation? Or are they particular instances of control, in spite of showing the morphology of inflected infinitives? We will argue that the properties of these constructions indicate that they are indeed instances of control (for the sake of simplicity, we will use shorter examples, with matrix verb querer 'to want').

First, the empty subject in the embedded domain does not alternate with a lexical subject (see (31)); secondly, an empty embedded subject with an arbitrary reading was never found (see (32)) and, finally, the sloppy reading under ellipsis, which characterizes control, is maintained (see (33)). We did not find in corpora cases such as (31) or (32) and we confirmed all the judgments with EP informants.
(31) a. *Os pais quiseram viajarem os filhos de the parents wanted travel.INF.3PL the children by comboio.
train
b. *Os pais quiseram os filhos viajarem the parents wanted the children travel.INF.3PL de comboio. by train
(32) *A Maria quis ec arb fazerem o trabalho. the Maria wanted do.INF.3PL the work 

$\neq$ Pedro prefers for the children to receive a medal

These facts suggest that that the empty category in the subject embedded position is PRO and not pro; these are thus pseudo-inflected infinitives or controlled inflected infinitives.

The results from a judgment test performed by EP informants contributed to our understanding of this puzzling phenomenon. Although some asymmetries were observed, in general speakers rejected data similar to (27)-(30), where an Exhaustive Control (EC) reading obtains; some of them even noticed the redundancy of overt inflection in both verbs. Interestingly, some of these speakers signal a slight contrast between (27)-(28) and (29)(30), and consider that the latter are better than the former. What is of particular relevance is that (29)-(30) are instances of tense independent contexts, as opposed to (27) and (28), which constitute tense dependent contexts. ${ }^{8}$

Nevertheless, and allowing to add a relevant point to the discussion carried out here, some of the speakers who reject (27)-(30) do not totally reject (34), with a Partial Control (PC) reading: the embedded subject is anaphorically dependent on a higher DP, but it is not exhaustively controlled by it.

For these speakers, mismatching in number and matching in person is not completely excluded (see (34)), whereas mismatching in person is completely degraded (see (35)) .
(35) ??/*Eu decidi / preferi
$\mathrm{ec}_{2}$ irem
ao cinema.
I decided/preferred
go.INF.3PL to.the cinema

Still, when a PC reading may obtain, some informants do not totally reject the possibility of a mismatch in person. However, some of them report a contrast between (34) and (36):
(36) ??O João ${ }_{1}$ decidiu/preferiu ec $e_{1+}$ irmos the João decided / preferred go.INF.1PL ao cinema.
to.the cinema

Again, for these speakers, the possibility of having a controlled inflected infinitive is restricted to tense independent contexts, since they report a contrast between (34), with an independent tense CP, and (37), with a dependent tense $\mathrm{CP}$ : 


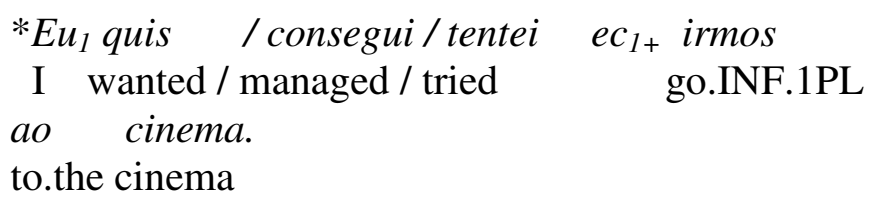

These results seem to show the two following tendencies. First, speakers of EP reject controlled inflected infinitives in dependent tense CPs and with EC reading. Thus, utterances like those in (27)-(30) that were rejected by our informants are probably cases of performance errors. These performance errors make the Agree operation underlying control visible, which does not have a morphologically overt counterpart in the standard grammar of EP. Secondly, some EP speakers marginally accept controlled inflected infinitives as a strategy to make PC readings explicit in independent tense contexts, although they generally disallow mismatching in person. This finding is not completely in line with Sheehan's (2012) results. In fact, she claims that PC with inflected infinitive does not require any kind of matching (in person or in number) between the controller and the controllee; according to her, "as long as the controller is a potential proper subset of the referent of PRO, the embedded subject has syntactic features to match its semantics, regardless of the features of the controller" (p. 20). Yet, the slight contrast between (34) and (36) in our informants' judgements supports the claim that mismatch in person is generally rejected: there is a reading of (36) in which the controller is a proper subset of the controllee, but (36), with mismatching person features, is still worse than (34), which presents matching person features.

Notice that the occurrence of controlled inflected infinitives has been noticed in other varieties of Portuguese, in particular in B(razilian) $\mathrm{P}$ (ortuguese). Modesto (2010, 2011) suggests that the occurrence of infinitival inflection in BP depends on the matrix verb. In complements to propositional (declarative and epistemic) verbs, inflected infinitives are possible (though not obligatory), both with EC (see (38)) and PC (see (39)) readings. ${ }^{9}$

Os cientistas acreditam ec $_{1}$ ter(em) descoberto
the scientists believe have.INF(.3PL) discovered
a cura do câncer
the cure of.the cancer
$E u_{1}$ acredito ec $e_{1+}$ estarmos de acordo.
I believe be.INF.1PL of agree

(Modesto 2011, (6b) \& (7b))

In complements to desiderative (and, generally, to future irrealis OC) verbs, inflection on the infinitive is obligatory if a PC reading is intended. These examples are similar to the non-standard EP example (34).
(40) a.
A Maria $_{1}$ decidiu
$e c_{1+}$ viajarem
the Maria.FEM decided.3PL
travel.INF.3PL 
juntas.

together.FEM

b. As meninas I $_{1}$ decidiram $e c_{1+}$ viajarem

the girls.FEM decided.3PLU travel.INF.3PLU

todos juntos.

all.MASC together.MASC

(Modesto 2011, (8b) \& (8c))

However, BP disallows inflected infinitives in complements of desiderative verbs with an EC reading (see (41)) and in complements of interrogative, implicative, modal and aspectual verbs with both EC and PC readings (see (42)):

(41) As meninas decidiram viajar(*em) juntas. the girls.FEM decided.3PL travel.INF.3PL together.FEM
Os meninos tentaram abrir $\left({ }^{*}\right.$ em $)$ open.INF.3PLU the safe the children tried $o$ cofre.

(Modesto 2011, (8a))

(Modesto 2011, (9c))

Summarizing, we seem to find similar tendencies in EP and BP (which deserve further research): tense dependence and EC readings seem to exclude the possibility of inflection in the embedded infinitive. In contrast, some EP speakers marginally accept inflected infinitives with PC reading in tense independent complements, provided no person mismatching occurs (in line with the tendency in BP).

\subsection{The analysis of controlled inflected infinitives and Control as Agree}

As described in the previous section, controlled inflected infinitives occur in spoken and written data, although this is not a property of standard EP. The occurrence of these infinitives in EC contexts (the cases that we take to be performance errors) may be accounted for within a theory of Control as Agree and of inflected infinitives which considers the occurrence of overt inflection in the infinitive and licensing of pro/overt subject two independent facts - something independently needed to account for c(ontrolled)-subjunctives in the Balkan languages (Landau 2004, a.o.):
(43) Ivani $_{i}$ uspja
$P R O_{i / *_{j}}$ da ostane
pri nego.
Ivan managed.3SG PRO PRT stay.3SG with him 'Ivan managed to stay with him.'

(Bulgarian, Krapova \& Petkov 1999, apud Landau 2004, 827)

Both controlled inflected infinitives and c-subjunctives in the Balkan languages share the following properties, resulting from Agree between matrix T and embedded C (Landau 2004, 827): (a) the embedded subject is necessarily null and controlled by a c-commanding DP in the matrix clause; 
(b) the phi-features of matrix $\mathrm{T}$ are shared by embedded $\mathrm{T}$ via Agree, which may have a morphologically overt counterpart. Therefore, a theory of subject Control as Agree can explain overt morphology in the infinitival form as a result of this operation in a language where inflected infinitive is available. Agree has a visible morphological effect on the embedded C-T, obtained via spreading of the phi-features of matrix $\mathrm{T}$; if inflection in this case is just an effect of Agree, this accounts for the fact that totally disjoint subjects are generally not attested.

As we have already mentioned, it is a relevant fact that our proposal treats overt inflection and nominative Case as independent facts. In fact, whereas true inflected infinitives take pro or an overt DP as a subject with nominative Case, controlled (pseudo-) inflected infinitives are obligatorily controlled structures with PRO subjects, in spite of presenting overt inflection.

The derivation of PC, however, is much more problematic, as Sheehan (2012) showed at length, especially concerning instances of true PC, with inflected infinitive ${ }^{10}$. In fact, as Modesto $(2010,2011)$ also remarks, true PC is a challenge for Hornsteins's Movement Theory of Control. In particular, how does a singular subject (the controller) trigger plural agreement on the embedded verb and singular agreement on the matrix verb?

But PC is also challenging under a theory of Control as Agree, because, in this case, mismatching in some phi-features (namely, number or even person) is allowed to make PC readings explicit. If PRO always has unspecified phi-features ([ф:?]) which are valued by Agree, we expect the phi-features of PRO to match the phi-features of the controller. In order to solve this question, Sheehan (2012) develops an analysis based on defective thematic intervention (Chomsky 2000): matrix $v$ probes the DP subject in the complement domain, and forms a dependency with it; in this way, $v$ values its unvalued uninterpretable D-feature. Since the DP is case-marked, it becomes inactive and cannot merge with $v$; then, a DP is externally merged, receiving a theta-role from $v$. Since $v$ has agreed with the embedded DP, the external argument's referential index must be a proper subset of the embedded DP referential index.

However, there is a gradient acceptability in PC contexts which is not accommodated by Sheehan's analysis, although the author presents empirical evidence for it: first, number mismatch is more acceptable than person mismatch (second, $\mathrm{PC}$ is better in tense independent contexts). The acceptability of number mismatch may be accounted for if (number) agreement may be semantic (Landau 2004 suggests that number agreement is merely semantic), a hypothesis compatible with a PRO analysis of the embedded subject in (44) ${ }^{11}$ :

(44) ?Eu $u_{1}$ decidi / preferi ec $c_{1+}$ irmos ao cinema. I decided/preferred go-IF-1PL to.the cinema 
Up until now, we have been assuming, on the basis of the judgments of (31) to (33), that these inflected infinitives are controlled, i.e. they show morphological inflection but do not have the syntactic properties of inflected infinitives, namely they do not license a pro / overt subject. However, since independent tense seems to facilitate the occurrence of the inflected infinitive, we cannot exclude that some speakers have developed a grammar in which a partially incomplete (or defective) $\mathrm{T}$ ([T $\tau: ?$; TPpt: val]) checks nominative, again in line with Sitaridou's (2006) claim that T defectiveness must be dissociated from phi-defectiveness. In such a grammar, these sentences would be true syntactic inflected infinitives with pro subjects.

\section{Conclusions}

The facts presented in this paper allowed discussing classical approaches to the distribution of inflected infinitives which connected it to tense dependence, defined as a purely lexical property. We have shown that not only (obligatory) tense dependence does not by itself explain the distribution of inflected infinitives but also that it is not a purely lexical property, since it is restricted to Control contexts. We have shown that the distribution of inflected infinitives in complement clauses is related instead to the temporal orientation of the embedded complement, which is determined by the matrix verb.

Actually, the position taken in this paper is that inflected infinitive should be understood in the broader set of infinitives, including controlled infinitives. We have thus characterized the contexts for inflected infinitives as contexts escaping the conditions for obligatory control (i.e. control as Agree) - this is the case of NOC contexts as well as the particular OC contexts where inflected infinitives occur. Maintaining an approach to control which follows the lines of Landau (2000, 2004), we have taken the occurrence of overt inflection in the infinitive and the licensing of pro/overt subject as two independent facts. This allowed developing an account of controlled inflected infinitives in non-standard EP. We showed that, for most speakers, these are not true inflected infinitives (we called them "controlled/pseudo-inflected infinitives"), to the extent that they do not license a pro /overt subject even though they show up with morphological agreement, i.e. they are morphologically inflected but do not have the syntactic properties of inflected infinitives. We argued that if we take Control to be Agree between matrix T and embedded C-T, we can account for these controlled inflected infinitives: we suggested that morphological agreement is in this case the spell-out of the abstract Agree operation giving rise to Control. Controlled inflected infinitives are thus in this sense an argument for an Agree theory of Control, in the case of EC readings. 


\section{References}

Ambar, Manuela. 2007. "Verb Movement and Tense - EPP and T-Completeness". In Proceedings of the XXXII Incontro di Grammatica Generativa, ed. By .M. Cecilia Picchi, and Alan Pona, 1-20. Alessandria: Edizioni dell'Orso.

Ambar, Manuela, Esmeralda Negrão, Rita Veloso, and Luís Graça. 2009. "Tense Domains in BP and EP $-v \mathrm{P}, \mathrm{CP}$ and phases". In Romance Languages and Linguistic Theory 2007, ed. by Enoch O. Aboh, Elisabeth van der Linden, Josep Quer, and Petra Sleeman, 1-24. Amsterdam: John Benjamins.

Chomsky, Noam. 2000. "Minimalist Inquiries". In Step by Step: Essays on Minimalst Syntax in Honour of Howard Lasnik, ed. by Roger Martin, David Michaels, and Juan Uriagereka, 89-155. Cambridge, Mass.: The MIT Press.

Chomsky, Noam. 2008. "On Phases". In Foundational Issues in Linguistic Theory, ed. by Robert Freidin, Carlos P. Otero, and Maria-Luisa Zubizarreta, 133-166. Cambridge, MA: The MIT Press.

Cunha, Luís F., and Purificação Silvano. 2006. "A interpretação temporal dos infinitivos em orações completivas de verbo". In Textos Seleccionados do XXI Encontro Nacional da Associação Portuguesa de Linguística, ed. by Fátima Oliveira, and Joaquim Barbosa, 303-314. Lisboa: APL.

Declerck, Renaat. 1991. Tense in English: Its Structure and Use in Discourse. London: Routledge.

Duarte, Inês, Anabela Gonçalves and Ana Lúcia Santos 2012. "Infinitivo flexionado, independência temporal e controlo" In Textos Selecionados. XXVII Encontro Nacional da Associação Portuguesa de Linguística, ed. by Armanda Costa, Cristina Flores and Nélia Alexandre. Lisboa: APL.

Gonçalves, Anabela. 1999. Predicados complexos verbais em contextos de infinitivo não preposicionado do Português Europeu. $\mathrm{PhD}$ thesis, University of Lisbon.

Gonçalves, Anabela, Luís F. Cunha, and Purificação Silvano. 2010. "Interpretação temporal dos domínios infinitivos na construção de reestruturação do Português Europeu". In Textos Seleccionados do XXV Encontro Nacional da Associação Portuguesa de Linguística, ed. by Ana M. Brito, Fátima Silva, João Veloso, and Alexandra Fiéis, 435-447. Lisboa: APL.

Kamp, Hans \& Uwe Reyle. 1993. From Discourse to Logic: Introduction to Modeltheoretic Semantics of Natural Language, Formal Logic and Discourse Representation Theory. Dordrecht: Kluwer.

Landau, Idan. 2000. Elements of Control. Structure and Meaning in Infinitival Constructions. Dordrecht: Kluwer.

Landau, Idan. 2004. "The Scale of Finiteness and the Calculus of Control". Natural Language \& Linguistic Theory 22(4): 811-877.

Modesto, Marcello. 2010. "What Brazilian Portuguese Says About Control: Remarks on Boeckx and Hornstein". Syntax 13(1):78-96.

Modesto, Marcello. 2011. "Infinitivos flexionados em Português Brasileiro e sua relevância para a Teoria do Controle". In Estudos da Linguagem, Casamento entre Temas e Perspectivas, ed. by Dermeval da Hora, and Esmeralda Negrão, 63-87. João Pessoa: Idéia.

Raposo, Eduardo. 1987. "Case Theory and Infl-to-Comp: The Inflected Infinitive in European Portuguese". Linguistic Inquiry 18(1): 85-109. 
Sheehan, Michelle. 2012. "A New Take on Partial Control: Defective Thematic Intervention". Occasional Papers in Linguistics 6: 1-47.

Silvano, Purificação. 2002. Sobre a semântica da sequência de tempos em Português Europeu. Análise das relações temporais em frases complexas com completivas. MA Thesis, University of Minho.

Sitaridou, Ioanna. 2006. "The (Dis)Association of Tense, phi-features EPP and Nominative Case: Case Studies from Romance and Greek". In Studies on Agreement, ed. by João Costa, and M. Cristina Figueiredo Silva, 243-260. Amsterdam: John Benjamins.

${ }^{1}$ This work was developed at Centro de Linguística da Universidade de Lisboa (PEstOE/LIN/UI0214/2013), within the project Complement Clauses in the Acquisition of Portuguese (PTDC/CLE-LIN/120897/2010), funded by Fundação para a Ciência e a Tecnologia. We thank the audiences of $38^{\text {th }}$ Incontro di Grammatica Generativa, $22^{\text {nd }}$ Colloquium on Generative Grammar and Going Romance 2012, as well as Pilar Barbosa, Idan Landau, Rui Marques and Purificação Silvano, for their comments on previous versions of this paper.

2 The analysis presented in this section is meant to account for inflected infinitives in standard contexts. Whenever we refer to inflected infinitives in non-standard varieties of $\mathrm{EP}$, we use the terms pseudo-inflected infinitives/controlled inflected infinitives.

${ }^{3}$ As usual, we use "irrealis" for non factual readings (both virtual and counterfactual ones).

${ }^{4}$ In a system where derivations are formed through Merge, that is, bottom up, when the embedded $\mathrm{C}$ is selected for by some $\mathrm{X}^{\mathrm{o}}$ in the upper clause, we must assume that there is over-generation. Nothing prevents a complete infinitival CP phase to merge with a (matrix) $\mathrm{V}$ which does not select for such complements (e.g. querer 'want'): the derivation will crash, in that case.

${ }^{5}$ For the notion of phase, see Chomsky (2008); for infinitival incomplete phases in EP, see Ambar (2007), Ambar et al. (2009).

${ }^{6}$ For the defectiveness of tense dependent complements in other contexts, see Gonçalves (1999).

7 The picture outlined here also allows to suggest that tense dependence is parasitic on specified temporal orientation: if the embedded $\mathrm{CP}$ is $[\tau . v a l]$, then it is [TPpt: val]; the CP is [TPpt: ?] iff it is also [ $\tau$. ?]. This means a relation between temporal orientation and tense dependence that goes beyond the proposal developed here and which is left for future research.

${ }^{8}$ The fact that independent tense contexts facilitate the occurrence of inflected infinitive is also noticed by Sheehan (2012).

${ }^{9}$ The verb classes are proposed by Modesto, following Landau.

${ }^{10}$ Sheehan (2012) distinguishes true PC (with inflected infinitive) from fake PC (with noninflected infinitive). She proposes that fake PC is actually EC. We will not discuss fake PC in this paper.

${ }^{11}$ Other cases of semantic agreement have been noticed in EP. A case in point is agreement with a subject DP with a partitive expression (see i).

(i) A maioria dos alunos compraram os livros. the majority.3SG of.the students bought.3PLU the books 'The majority of the students bought the books.' 